\title{
Implementasi Genre Based Approach Untuk Meningkatkan Keterampilan Menulis Explanation Text
}

\section{Ananda Rival Prakoso ${ }^{1 *}$, Putu Seriardana ${ }^{2}$, Luh Diah Surya Adnyani ${ }^{3}$}

${ }^{123}$ Jurusan Pendidikan Bahasa Inggris Universitas Pendidikan Ganesha

\section{ART I CLE I N F O}

Article history:

Received January 21, 2021

Revised February 03, 2021

Accepted April 08, 2021

Available online May 25, 2021

\section{Kata Kunci:}

Keterampilan menulis, penelitian tindakan kelas, Genre based approach

Keywords:

Writing, Clasroom action research, Genre based approach

\begin{abstract}
A B S T R A K
Menulis adalah salah satu keterampilan produktif dalam belajar bahasa Inggris. Ada berbagai macam pendekatan untuk meningkatkan keterampilan menulis. Salah satunya adalah dengan pendekatan Genre Based Approach. Menulis adalah salah satu keterampilan yang susah dikuasai peserta didik, oleh karena itu penelitian ini dilakukan untuk mengatasi masalah keterampilan menulis dengan mengimplementasikan pendekatan Genre based approach dalam menulis teks explanation. Metode penelitian yang digunakan adalah penelitian tindakan kelas. PTK akan berjalan dalam dua siklus. Fokus dalam penelitian ini akan dibatasi pada hasil unjuk kerja menulis peserta didik yang akan dinilai menggunakan rubrik menulis. 19 orang peserta didik kelas 11 IIS 1 di SMA Laboratorium Undiksha dipilih menjadi subjek penelitian. Pre-test dan post-test digunakan untuk mengambil data nilai hasil unjuk kerja menulis peserta didik. Sebagai tambahan, data yang diperoleh akan dianalisis dengan dukungan dari lembar observasi.. Hasil dari penelitian yang dilakukan menunjukan bahwa masalah peserta didik dalam kurangnya keterampilan menulis dapat teratasi dengan digunakannya pendekata Genre based approach. Ini ditunjukkan dengan adanya lebih dari 75\% peserta didik memiliki nilai diatas KKM dan memiliki peningkatan nilai keterampilan menulis pada post-test.
\end{abstract}

\begin{abstract}
A BS TR A C T
Writing is one of productive skills in English. There are many approaches in improving writing skills. One of them is by using Genre Based Approach. Writing is considered as difficult skill to be mastered by students. Therefore, this study is meant to overcome student's writing problem by implementing Genre Based Approach. Classroom Action Research was chosen as research model which was suitable for the problem which have been identified. The study was done in two cycles. The focus of the study was limited to student's writing evaluated by using writing scoring rubric. 19 students of 11 IIS 1 in SMA Laboratorium Undiksha were chosen as research subject. Pre-test and post-test were used as instrument in collecting students' writing product. In addition, the data which has been discussed were supported by the result of observation sheet. The result of study showed that student's weakness in writing have been overcome after being implemented Genre Based Approach. This is proven by the presence of more than 75\% students have been surpass the minimum standard score. Not only that, but also there were improvement in student's writing skill in post-test.
\end{abstract}

\section{Pendahuluan}

Pendidikan merupakan suatu proses yang diperlukan untuk mendapatkan keseimbangan dan kesempurnaan dalam perkembangan individu maupun masyarakat. Penekanan pendidikan dibanding dengan pengajaran terletak pada pembentukan kesadaran dan kepribadian individu atau masyarakat di samping transfer ilmu dan keahlian. Dengan proses semacam ini suatu bangsa atau negara dapat mewariskan nilai-nilai keagamaan, kebudayaan, pemikiran dan keahlian kepada generasi berikutnya, sehingga mereka betul-betul siap menyongsong masa depan kehidupan bangsa dan negara yang lebih cerah (Nurkholis, 2013). Belajar merupakan proses internal yang kompleks. Yang terlibat dalam proses internal tersebut adalah seluruh mental yang meliputi ranah-ranah kognitif, afektif dan ranah psikomotorik. Proses belajar yang mengaktualisasikan ketiga ranah tersebut tertuju pada bahan belajar tertentu (Nidawati, 2013).

Keterampilan menulis merupakan keterampilan berbahasa yang dipergunakan untuk berkomunikasi secara tidak langsung dan secara tatap muka dengan orang lain. Menulis merupakan suatu kegiatan produktif dan ekspresif. Keterampilan menulis ini tidak akan datang secara otomatis, melainkan harus melalui latihan dan praktik yang banyak dan teratur. Dalam kegiatan menulis diperlukan pengetahuan yang luas dan pola pikir yang logis (Sismulyasih Sb, 2015).

Bahasa Inggris adalah Bahasa internasional yang memiliki peranan penting dalam kehidupan masyarakat dunia sekarang ini. Banyak keterampilan berbahasa inggris yang digunakan untuk berkomunikasi dengan berbagai macam orang di berbagai belahan dunia. Keterampilan berbahasa Inggris 
bisa dibagi menjadi dua bagian terpisah, yaitu productive dan receptive skill. Productive berarti mengahasilkan suatu produk dan receptive berarti kemampuan menerima informasi. Salah satu keterampilan productive atau memproduksi yang akan dibahas dalam penelitian ini adalah keterampilan menulis. Menulis adalah salah satu keterampilan yang tidak terpisahkan dalam Bahasa inggris . Keterampilan menulis bisa dikategorikan keterampilan yang kompleks. Hal tersebut dikarenakan dalam menulis, sang penulis diharapkan mampu mengakumulasikan pengetahuan mereka kedalam bentuk tulisan. Mengakumulasi dapat diartikan bahwa penulis berpikir secara kontinyu untuk membuat tulisannya saling terkoneksi satu sama lain (Boardman, Cynthia. A, and Frydenberg, 2002) . (Oshima, Alice, \& Hogue, no date) juga menyatakan bahwa menulis adalah suatu keterampilan kreatif yang dilakukan secara berkelanjutan.

Kurikulum 2013 sebagai kurikulum nasional sendiri telah memfasilitasi guru dengan arahan untuk mengajarkan keterampilan menulis. Di dalam silabus telah disisipkan kompetensi keterampilan menulis untuk mendorong peserta didik mengasah keterampilan menulis mereka. Salah satunya yang menjadi focus penelitian ini tertuang di dalam silabus mata pelajaran Bahasa Inggris kelas XI SMA KD 4.8 menyatakan "Menyusun teks explanation lisan dan tulis secara kontekstual terkait gejala alam atau sosial yang tercakup dalam mata pelajaran lain di kelas XI dengan memperhatikan fungsi sosial, struktur teks, dan unsur kebahasaan secara benar dan sesuai konteks" Kompetensi minimum yang diharapkan untuk peserta didik mampu mencapainya adalah menyusun sehingga dapat disimpulkan bahwa peserta didik akan memproduksi teks tulis dalam bentuk teks explanation. Berkaitan dengan keterampilan menulis, dalam obervasi yang telah dilakukan selama empat minggu sebelumnya di SMA Lab Undiksha, ditemukan bahwa keterampilan menulis peserta didik khususnya menulis teks fungsional masih kurang. Hal ini dibuktikan, lebih dari $75 \%$ peserta didik memiliki nilai unjuk kerja menulis dibawah Kriteria Ketuntasan Minimal (KKM). Selain itu, ditemukan juga dalam tulisan peserta didik masih banyak melakukan kesalahan dalam sisi grammatical. Sebagai contoh dalam text personal letter, "Me and my family go to beach", "I hope I not to hurt she because I kick the ball to harder.". Another examples from explanation text pretest are "Tsu is meaning wve and nami is meaning harbor", "Tsunami happen because earth plate crashing". Contoh Kalimat-kalimat tersebut diambil dengan metode random sampling dari lembar kerja peserta didik. Itu membuktikan bahwa peserta didik masih melakukan kesalahan-kesalahan pada penggunaan grammar, pemilihan vocab, dan ditemukan juga kurangnya pengembangan isi paragraf yang memang benar adanya.

Masalah yang telah diketahui tidak hanya didapatkan dan disimpulkan dari lembar kerja peserta didik, namun juga didapatkan dari jawaban peserta didik dalam interview singkat secara acak kepada mereka. Didapatkan data, bahwa peserta didik tidak tahu kesalahan yang mereka lakukan dalam tulisannya sehingga dapat disimpulkan kesadaran mereka akan kesalahan yang mereka buat dalam tulisan itu kurang. Sebagai tambahan, mereka umumnya juga menyatakan kesulitan dalam mengembangkan ide pokok dalam tulisan mereka.

Selain melakukan oral interview kepada peserta didik, rekan guru mata pelajaran Bahasa Inggris juga dipilih untuk di wawancara. Hasil yang didapatkan dari wawancara singkat tersebut adalah, ditemukan suatu masalah bahwa banyak peserta didik yang memulai proses menulis dengan menggunakan L1 atau menggunakan Bahasa Indonesia. Didapatkan juga jawaban bahwa feedback telah diberikan, namun proses revisi enggan dilakukan oleh peserta didik. Selain itu, penggunaan google translate umum dilakukan oleh siswa sehingga mereka hanya copy paste dari tulisan yang mereka alihbahasakan. Dengan demikian porsi penggunaan Bahasa Inggris sebagai pembelajaran Bahasa menjadi berkurang. Dari beberapa masalah-masalah didalam kelas yang telah dijabarkan sebelumnya, ditemukan beberapa diagnose sumber penyebab masalah yang muncul. Yang pertama adalah karena feedback dari guru tidak ditanggapi oleh peserta didik dengan merevisi tulisan mereka secara mandiri. Yang kedua adalah tidak adanya waktu revisi didalam kelas untuk peserta didik mengoreksi kesalahan yang dilakukan. Yang ketiga adalah penggunaan Bahasa Indonesia dalam google translate..

Ada beberapa strategi yang bisa diterapkan untuk mengatasi masalah-masalah yang mucul dikelas berkaitan dengan keterampilan menulis. Salah satunya Product Based approach dengan kelebihan tulisan peserta didik menjadi lebih teratur sesuai kaidah penulisan atau struktur penulisan teks yang dirujuk. Teks authentic yang dijadikan model oleh peserta didik akan mampu ditiru oleh mereka sehingga didapatkan tulisan yang rapi sesuai text model. Strategi lainya yaitu Process Based Approach yang memfokuskan kepada penulisan kreatif. Peserta didik diberikan kesempatan untuk menuangkan ide-ide mereka kedalam bentuk tulisan-tulisan menjadi banyak draft. Draft-draft tulisan peserta didik nantinya dikumpukan dan akan menjadi tulisan utuh dari gabungan ide-ide yang dimiliki peserta didik. Dua strategi tersebut memiliki kelebihan dan kekurangan sehingga diputuskan untuk memilih strategi penegngah dari dua strategi tersebut, yaitu Genre Based Approach sebagai strategi pendekatan untuk mengatasi masalah peserta didik dalam menulis dengan mengakuisisi kelebihan-kelebihan dari dua aprroeach yang ditawarkan sebelumnya. 
Genre Based Based Approach adalah strategi pendekatan pembelajaran menulis yang menggabungkan antara pendekatan product dan proses. menyatakan bahwa Genre Based Approach memiliki empat stages utama yang bisa diterapkan dalam langkah-langkah pembelajaran yaitu Building Knowledge of Fields, Modelling of Text, Jont Construction, dan Independent Construction of text. Melalui langkah-langkah dalam strategi tersebut peserta didik diharapkan memiliki lebih banyak waktu untuk membuat draft dan membuat revisi atas draft yang telah dibuat. Sebagai tambahan, karena Genre Based Approcah adalah penggabungandari product dan proses approach, (Kim, J., \& Kim, 2005) dalam jurnalnya menemukan bahwa penggabungan dua strategi tersebut bisa membantu meningkatkan keterampilan menulis siswa. Selain Kim, (Hasan, M. K., \& Akhand, 2010) dalam jurnalnya juga menemukan Genre Based approach efektif dalam mengajarkan keterampilan menulis siswa. Dengan memperhatikan masalahmasalahyang terpapar seperti diatas dan kesesuaian strategi yang dipilih untuk mengatasi masalah yang ada, penelitian ini memiliki tujuan untuk menerapkan strategi GENRE BASED BASED APPROACH guna meningkatkan keterampilan menulis peserta didik kelas XI SMA.

Dengan adanya penelitian ini, diharapkan keterampilan menulis peserta didik meningkat dan memberikan variasi pembelajaran kepada guru untuk mempermudah pembelajaran writing.

\section{Metode}

\section{Rancangan Penelitian}

Rancangan penlitian yang akan digunakan adalah penelitian tindakan kelas (PTK). Tipe penelitian ini bertujuan untuk mengatasi masalah yang ditemukan didalam kelas dimana diharapkan terjadinya peningkatan kemampuan peserta didik. Penelitian tindakan kelas dilakukan dalam beberapa siklus sampai masalah-masalah yang ditemukan teratasi. Penelitian tindakan kelas adalah suatu usaha sistematis dari guru ataupun praktisi pendidikan lain untuk mendapatkan informasi tentang seberapa baik guru mengajar, seberapa jauh peserta didik belajar, dengan tujuan sebagai tindakan refleksi untuk mendapatkan perubahan positif dengan teratasinya masalah yang telah teridentifikasi . Setiap siklus menggunakan model pelaksanaan yang memiliki empat tahapan utama, yaitu: (1) Rencana tindakan, (2) Pelaksanaan tindakan, (3) Pemantauan dan evaluasi, (4) Refleksi (Arikunto, 2017). Penelitian ini (Mills, 2000)bertujuan untuk mengatasi masalah peserta didik dalam pembelajaran menulis. Penelitian ini pada umumnya dilakukan lebih dari satu siklus tergantung tingkat keberhasilan penelitian yang dirumuskan.

\section{Subjek Penelitian}

Subjek yang dipilih adalah peserta didik kelas 11 di SMA Laboratorium Undiksha Singaraja pada semester genap tahun ajaran 2018/2019.

\section{Skenario Tindakan}

Seperti yang disebutkan sebelumnya, rancangan PTK menggunakan empat tahapan, yaitu; Rencana tindakan, pelaksanaan tindakan, pemantauan atau evaluasi, dan refleksi. Secara garis besar bisa dilihat didaftar sebagai berikut:

1. Menyiapkan, membuat, dan mengonsultsikan instrument penelitian

2. Membuat jadwal penelitian

3. Melaksanakan pre-test untuk mengetahui kemampuan awal peserta didik

4. Mengkonfirmasi apakah masalah sebagian besar peserta didik sudah seperti yang ditemukan.

5. Melaksanakan treatment dan mengevaluasi treatmen yang telah dilakukan

6. Melaksanakan post-test untuk mengetahui hasil akhir dari treatment

7. Melakukan pengolahan data (pengurangan, pemilahan, pengolahan)

8. Menganalisis data yang telah diolah

9. Melengkapi data yang masih kurang dan menguatkan datayang sudah ada

10. Membuat kesimpulan dari hasil data yang telah dianalisis

Untuk memperjelas tahapan-tahapan penelitian maka akandibagi menjadi empat bagian.

Tahap Rencana Tindakan

1) Menyusun scenario pembelajaran yang akan dilaksanakan

2) Menyiapkan materi pembelajaran

3) Menyiapkan media pembelajaran

4) Menyiapkan, membuat, dan mengonsultsikan instrument/alat-alat penelitian

5) Membuat jadwal kegiatan

Tahap Pelaksanaan TIndakan

6) Melaksanakan proses pembelajaran sesuai dangan jadwal dan rencana pembelajaran yang sudah disiapkan.

7) Memberitahukan tujuan penelitian yang akan dicapai di akhir

8) Mengenalkan dan menerapkan strategi Genre Based Approach dalam pembelajaran dengan peserta didik 
9) Melakukan penilaan terhadap keberhasilan siswa baik keberhasilan proses maupun keberhasilan produk

Tahap Pemantauan dan Evaluasi

10) Observasi dilakukan dengan menggunakan lembar observasi yang telah dibuat sebelumnya. Lembar observasi yang berisi daftar sikap yang ditunjukkan oleh peserta didik selama pembelajaran akan menjadi bahan refleksi untuk siklus selanjutnya.

11) Kegiatan / aktivitas yang terjadi selama tahapan pelaksanaan dicatat untuk kemudian dievaluasi sebagai bahan refleksi padatahap selanjutnya

Tahap Refleksi

12) Refleksi dilakukan untuk menanggapi perubahan/hal-hal yang terjadi selama pelaksanaan treatmen.

13) Refleksi juga ditujukan untuk melihat kemungkinan-kemungkinan kelemahan pelaksanaan tindakan pada siklus yang telah berlangsung. Hasil dari siklus ini ditujukan untuk mendapatkan gambaran dalam rangka penyempurnaan tindakan pada siklus berikutnya, juga sekaligus bermanfaat didalam memberikan solusi alternative tindakan sebagai bagian dari penyempurnaan tindakan yang telah dilaksanakan pada penelitian ini.

Refleksi terhadap pembelajaran juga harus dilakukan, mengingat dalam penelitian dibutuhkan kecocokan antara perencanaan pembelajaran dengan tujuan yang ingin dicapai di akhir pembelajaran. Hal ini dimaksudkan untuk mengetahui apakah pembelajaran yang berlangsung sudah sesuai dengan rencana penelitian atau belum. Selain itu, refleksi pembelajaran juga dimaksudkan untuk memperbaiki pelaksanaan pembelajaran agar menjadi lebih baik di siklus selanjutnya.

\section{Kriteria Keberhasilan Penelitian}

Indikator keberhasilan pada penelitian ini akan terfokus pada produk belajar peserta didik. Produk belajar bisa diartikan yaitu tulisan hasil unjuk kerja menulis yang dilakukan peserta didik selama dilakukan treatmen. Dalam hal ini, penelitian bisa dikatakan berhasil apabila terdapat peningkatan nilai hasil tulisan peserta didik dari tes awal. Selain itu dikatakan berhasil apabila ada setidaknya $75 \%$ dari jumlah total peserta didik berhasil melampaui KKM.

\section{Teknik Analisis Data}

Ada tiga tahapan yang dilakukan oleh penulis untuk menganalisis data-data yang iperoleh selama pelaksanaan penelitian. Berikut adalah tahapan-tahapan beserta pejelasannya: Pengumpulan dan penyeleksian data adalah pemrosesan data yang didapatkan dari treatmen yang dilakukan akan dikumpulkandan diseleksi sesuai kebutuhandata untuk menjawab rumusan masalah yang telah dibuat. Hal ini dilakukan untuk mempermudah peneliti dalam menganalisis data yangada dan memberikan kesempatan bagi pembaca untuk focus terhadap data yang berkaitan saja. Interpretasi data pemrosesan data yang telah diseleksi sesuai kebutuhan akan dijelaskan lebih lanjut sehingga bukan hanya menjadi data mentah. Kegiatan ini membantu untuk mengaitkan data yang didapat dengan rumusan masalah yang ada. Menyimpulkan data merupakan pelaksanaan tahapan setelah data diinterpretasikan, maka akan disimpulkan sesuai rumusan masalah yang ada. Penarikan kesimpulan bertujuan untuk menjawab rumusan masalah dari data yang telah dianalisis.

Teknik analisis data secara rinci seperti dibawah ini:

Data dalam rumusan masalah akan dijabarkan dalam bentuk penjelasan tentang maksud dan tujuan segala sesuatu hal yang dilakukan guru dikelas sesuai dengan stages yang telah dirancang. Hal tersebut akan didukung dengan data dari lembar observasi kelas. Penilaian unjuk kerja menulis peserta didik akan diassess oleh dua orang rater untuk menggunakan rubrik menulis yang telah dirancang sebelumnya. Nilai peserta didik yang telah didapatkan akan diolah menggunakan program excel yang kemudian akan diinterpretasikan oleh peneliti. Sebagai tambahan untuk menguatkan data, hasil kerja peserta didik akan diinterpretasikan sesuai skor yang didapat dengan dukungan beberapa sample random questionnaire yang telah dijawab oleh peserta didik sebelumnya. Hasilnya bisa digunakan untuk membantu menguatkan kesimpulan yang dirumuskan.

\section{Hasil Dan Pembahasan}

Hasil pada pelaksanaan observasi awal adalah dua hasil utama. Yang pertama adalah berdasarkan transkrip interview, didapatkan data bahwa peserta didik mendapatkan kesulitan dalam kegiatan unjuk kerja menulis. Mereka menambahkan kalau kesulitan mereka terdapat dalam kata-kata yang belum diketahui sehingga ini bisa dikategarokan kesulitan dalam segi vocabulary. Hal ini juga diaminkan oleh guru mata pelajaran pengampu kelas tersebut bahwa sebagian besar peserta didik masih memiliki nilai unjuk kerja menulis dibawah KKM. Kesulitan lainnya yang bisa diidentifikasi dari interview dengan guru diatas adalah kurangnya kemampuan peserta didik untuk mengembangkan ide tulisan yang dimana ini 
berkaitan dengan sisi organisasi text. Dari interview yang sudah dilakukan, didapatkan kesimpulan bahwa peserta didik umumnya mengalami kesulitan dalam melakukan unjuk kerja keterampilan menulis. Hal ini merujuk pada kurangnya peserta didik dalam segi grammar, vocabulary, dan organisasi teks.

Setelah dilakuknnya interview singkat, penulis melakukan Dalam tes unjuk kerja menulis yang diberikan pertama kali ini bertujuan untuk mengetahui kemampuan awal peserta didik sebelum treatmen dilakukan. Selain itu tes awal ini juga bertujuan untuk mengonfirmasi adanya masalah yang terjadi pada hasil tulisan peserta didik. Dengan nilai KKM yang ditentukan 75, didapatlah rncian sebanyak empat peserta didik atau $21 \%$ memiliki nilai diatas KKM dan sisanya sebanyak 15 orang memiliki nilai dibawah KKM atau 79\% dari total semua peserta didik. Dari sini didapatkan kesimpulan bahwa memang peserta didik memiliki masalah dengan keterampilan menulis.

\section{Siklus 1}

Setiap pertemuan didalam siklus satu akan dievaluasi untuk pembelajaran yang telah dilakukan. Evaluasi bertujuan untuk mengecek kesesuaian guru dalam mengajar dengan RPP yang telah dirancang sebelumnya. Selain itu, evaluasi berguna untuk melihat kekurangan-kekurangan yang mungkin terjadi selama pembelajaran, baik dari segi guru, peserta didik, maupun kondisi lingkungan. Tidak hanya kekurangan-kekurangan yang teridentifikasi, melainkan kelebihan-kelebihan yangada juga dicantumkan guna mempertahankan sisi lebih dari suatu pembelajaran untuk terus dilakukan. Berikut hasil evaluasi di setiap pertemuan yang telah berlangsung diurutkan dari kegiatan awal sampai kegiatan penutup.

Di pertemuan pertama, hal pertama yang bisa dievaluasi adalah waktu pelaksanaan game molor menjadi 10 menit dikarenakan peserta didik rata-rata memiliki pilihan kosakata yang sama sementara aturan game nya tidak memperbolehkan peserta didik menyebutkan kosakata yang sama. Selanjutnya, sebagian besar peserta didik masih terihat kurang aktif dalam menjawab pertanyaan guru. Dikarenakan menggunakan Bahasa inggris, sehingga guru harus membimbing peserta didik untuk menjawab menggunakan kalimat sederhana. Ini ditunjukkan dari adanya peserta didik yang menawar guru dengan meminta menjawab menggunakan Bahasa Indonesia. Kemudian, didalam kegiatan diskusi kelompok, ditemukan ada satu dua orang peserta didik kurang aktif membantu kelompoknya. Dia bisa bergerak ketika guru memberikan bimbingan kepada kelompoknya perihal pengerjaan tugas. Dalam kegiatan diskusi kelompok, waktu pengerjaan juga molor. Ini dikarenakan meskipun berkelompok, peserta didik cenderung tidak melakukan pembagian beban kerja kepada setiap anggota kelompok. Hal ini diketahui dari pengamatan guru secara langsung ketika mendatangi kelompok yang bersangkutan. Dikarenakan molornya waktu diskusi bersama, kegiatan presentasi hasil kerja juga molor sehingga guru harus mensiasati hal ini dengan mempersingkat waktu presentasi.

Selain kekurangan-kekurangan yang terlihat seperti diatas, kelebihan masih dapat ditemukan. Seperti contohnya, kemampuan guru untuk mengapresiasi jawaban peserta didik sehingga membuat peserta didik yang lain termotivasi untuk juga ikut menjawab. Selain itu, media yang guru pilih yaitu ilustrasi gambar membuat peserta didik juga lebih tertarik dalam menganalisis isi ilustrasi tersebut. Ini bisa ditemukan dari pengamatan langsung oleh guru bahwa peserta didik lebh fokus ke ilustrasi gambar sederhana untuk menjelaskan isi teks.

Di pertemuan kedua, molornya pelaksanaan game pada kegiatan apersepsi tidak terjadi. Pelaksanaan permainan sudah tepat sesuai rencana yang telah disusun. Selanjutnya hal yang bisa dievaluasi adalah molornya pengerjaan tugas dalam diskusi kelompok. Ini dikarenakan, peserta didik masih cenderung melakukan kesalahan berulang yaitu tidak membagi tugas antar anggota kelompok. Kemudian, peserta didik kurang aktif dalam mencatat informasi-informasi penting yang terdapat dalam video. Ini ditunjukkan dari sedikitnya informasi yang disertakan peserta didik didalam tulisannya. Kegiatan penutup sudah dilaksanakan dengan baik dengan guru mengemukakan kekurangan yang dilakukan peserta didik selema pembelajaran berlangsung. Selain itu, guru memberikan solusi dari alasan peserta didik melakukan kegiatan yang menjadi kelemahan mereka yang bisa diterima oleh peserta didik. Secara umum, pertemuan kedua ini telah sesuai dengan rancangan RPP yang telah disusun sebelumnya

Evaluasi lainnya adalah kurang lamanya kesempatan yang diberikan kepada peserta didik untuk merefleksi hasil kerja tulis yang telah mereka kumpulkan di pertemuan kedua. Hal ini diketahui dari tanggapan beberapa peserta didik yang masih ingin melihat koreksi pekerjaan tulis mereka ketika diminta untuk dikumpulkan kembali.

Dari nilai post-test 1 didapatkan data bahwa ada peserta didik atau $74 \%$ dari total peserta didik sudah mencapai lebih dari KKM. Namun ada 5 peserta didik atau $26 \%$ dari total masih belum mencapai KKM.

\section{Siklus 2}

Evaluasi tetap dilakukan sebagai bagian dari laporan hasil pengamatan di setiap siklus. Evaluasi bertujuan untuk mengecek kesesuaian guru dalam mengajar dengan RPP yang telah dirancang 
sebelumnya. Tidak hanya itu, evaluasi juga berguna untuk melihat kekurangan-kekurangan yang mungkin terjadi selama pembelajaran, baik dari segi guru, peserta didik, maupun kondisi lingkungan. Kelebihankelebihan yang tercatat juga masih perlu dicatat guna menjadi bagian dari pengamatan kelas. Berikut hasil evaluasi pada setiap pertemuan yang telah berlangsung diurutkan dari kegiatan awal sampai kegiatan penutup. Di pertemuan pertama, hal yang bisa dievaluasi adalah waktu pelaksanaan game di tahap apersepsi masih sedikit molor dari yang direncanakan. Hal ini masih lebih baik daripada di siklus pertama yang molor lebih dari 10 menit. Salah satu alasannya dikarenakan peserta didik sudah familiar dengan kosakata-kosakata yang terdapat dalam tema pertemuan ini seperti sudah dipelajaridi pertemuan sebelumnya. Selanjutnya, sebagian besar peserta didik sudah terihat lebih aktif dibanding sebelumnya dalam menjawab pertanyaan guru, meskipun masih ada satu dua peserta didik yang tidak memperhatikan. Kemudian, didalam kegiatan refleksi hasil tulisan, banyak yang enggan bertanya langsung kepada guru. Dia berani bertanya ketika guru memberikan mendekati bangkunya untuk memonitor peserta didik. Dalam kegiatan mengoreksi hasil tulisan secara bersama-sama, banyak peserta didik yang tidak menulis kembali tulisan yang telah dibenarkan. Hal ini diketahui dari pengamatan guru secara langsung ketika mendatangi peserta didik satu persatu. Keengganan peserta didik untuk berkonsultasi langsung sudah disiasati dengan baik oleh guru dengan memonitor secara langsung ke bangku-bangku peserta didik.

Kelebihan-kelebihan guru yang tercermin di siklus pertama tetap dipertahankan. Seperti contohnya, kemampuan guru untuk mengapresiasi jawaban peserta didik sehingga membuat peserta didik yang lain termotivasi untuk juga ikut menjawab tetap terlihat di siklus ini. Bahkan ditambahkan dengan pemberian reward nilai keaktifan peserta didik. Selain itu, kemampuan guru untuk manajemen waktu lebih baik daripada siklus sebelumnya. Hal ini terlihat dari ketepatan aktu setiap kegiatan yang dilakukan.

Evaluasi lainnya pada kegiatan post-test 2 adalah masih enggannya peserta didik untuk mengonsultasi hasil koreksian yang didapat dari guru, meski sudah dipancing guru untuk menanyakan langsung kepada guru. Selebihnya, situasi dan kondisi kelas cenderung kondusif selama pelaksanaan posttest. Kegiatan penutup berlangsung lancar dengan diberitahukannya progress peserta didik selama dilaksanakannya siklus. Dari nilai post-test 2 didapatkan data bahwa ada 18 orang peserta didik atau $94 \%$ dari total peserta didik sudah mencapai lebih dari KKM. Dilain pihak, ada satu orang peserta didik atau 6\% dari total masih belum mencapai KKM.

\section{Pembahasan}

Didalam subbab ini, akan dijelaskan kaitan-kaitan data yang didapatkan dari pelaksanaan tindakan pada siklus 1 dan siklus 2 dengan teori-teori yang digunakan. Sebagai tambahan, fokus penelitian akan berada pada ketercapaian indicator keberhasilan yang telah dirumuskan yang ditunjukkan dari adanya perubahan pada hasil belajar peserta didik di setiap siklus.

Berdasarkan tindakan yang telah dilaksanakan di dua siklus sebelumnya, penggunaan Genre based approach kepada peserta didik kelas 11 SMA Laboratorium Undiksha menunjukkan terjadinya peningkatan pada nilai ketreampilan menulis. Pertama-tama, peningkatan yang terlihat adalah bertambahnya prosentase peserta didik yang melampaui KKM dari keterampilan menulis. Perubahan prosentase kelulusan peserta didik ditunjukkan pada tabel berikut.

Tabel 1. Perubahan prosentase kelulusan

\begin{tabular}{llll}
\hline & Pre-test & Post-test 1 & Post-test 2 \\
Tidak lulus & $79 \%$ & $26 \%$ & $6 \%$ \\
\hline Lulus & $21 \%$ & $74 \%$ & $94 \%$ \\
\hline
\end{tabular}

Dapat dilihat prosentase peserta didik yang lulus, bertambah dari pada saat pretest awal yang hanya $21 \%$ dari total peserta didik. Pada saat post-test siklus 1 kelulusan peserta didik menjadi $74 \%$ dari total semua peserta didik. Karena indicator keberhadilan penelitian menyatakan harus ada lebih dari 75\% peserta didik yang lulus diatas KKM maka diputuskan untuk melanjutkan ke siklus 2. Pada siklus 2 prosentae kelulusan menjadi 94\%, sehingga indikator keberhasilan penelitian telah tercapai pada siklus 2.

Kemajuan yang tampak tidak hanya terlihat dari prosentase peserta didik yang lulus KKM, melainkan juga bisa dilihat dari nilai arata-rata khir kelas peserta didik mulai dari pre-test sampai posttest 2. Perubahan peningkatan bisa ditunjukkan dalam tabel berikut.

Tabel 2. Perubahan nilai rata-rata kelas

\begin{tabular}{lll}
\hline Pre-test & Post-test 1 & Post-test 2 \\
\hline
\end{tabular}




\begin{tabular}{llll}
\hline Nilai rata-rata kelas & 52.6 & 76.8 & 87.6 \\
\hline
\end{tabular}

Bisa dilihat perubahan nilai rata-rata kelas dari pre-test yang hanya mencapai nilai 52.6 dimana nilai tersebut berada dibawah KKM yang ditentukan. Kemudian dilaksanakan siklus 1 yang membuat nilai rata-rata kelas meningkat signifikan menjadi 76.8 dimana nilai tersebut sudah berada 1.8 poin lebih tinggi melampaui KKM. Peningkatan dari pre-tes ke post-test 1 yang signifikan sebesar 24.2 poin setelah dilaksanakan siklus 1 membuat nilai rata-rata kelas melampaui KKM yang membuat indicator keberhasilan penelitian sudah tercapai. Namun, karena indicator keberhasilan juga dilihat dari prosentase peserta didik, maka diputuskanlah untuk berlanjut ke siklus 2 . Kenaikan yang signifikan ini bisa dipengaruhi oleh kemampuan peserta didik untuk merevisi hasil tulisannya. Didalam proses menulis terjadi proses revisi dimana dalam proses tersebut, peserta didik membuat perubahan perubahan tulisan dari koreksi yang mereka dapat kedalam tulisan mereka selanjutnya. Hal ini juga didukung oleh peran guru untuk mengevaluasi hasil kerja peserta didik. Selain itu, penggunaan Genre based approach juga menunjang perubahan peserta didik dengan diberikan paparan text lebih banyak sehingga peserta didik dapat melakukan proses revisi dengan membandingkan tulisan mereka dengan text sumber dari guru. Faktor-faktor inilah yang membuat nilai peserta didik dapat meningkatkan nilai yang sebelumnya dibawah KKM menjadi 1.8 poin diatas KKM.

Didalam siklus 2 bisa terlihat terjadi peningkatan nilai keterampilan peserta didik sebesar 10.8 poin dari nilai semula. Apabila dilihat, kenaikan poin tidak sebesar dengan yang pertama. Ini bisa terjadi karena sudah banyak peserta didik yang melampaui batas KKM di siklus 1 maka perubahan yang terjadi pada tulisan mereka menjadi lebih sedikit dibandingkan dengan pre-test awal. Hal ini bisa terjadi karena peserta didik sudah menunjukkan perubahan pada post-test 1 sehingga mereka hanya memiliki sedikit hal untuk dikoreksi guru. Secara umum peserta didik hanya terfokus kepada peningkatan kualitas tulisan dibandingkan dengan melakukan perubahan dikarenakan sudah terlampauinya KKM dikelas tersebut. Peningkatan kualitas ini terjadi karena adanya tahapan refleksi dari tulisan peserta didik untuk kemudian dilakukan revisi bersama sehingga peserta didik bisa mengetahui pada sisi mana kekurangan yang tampak pada tulisan mereka. Selain dua peningkatan secara keseluruhan terlihat dari dua aspek sebelumnya yaitu prosentase kelulusan peserta didik dan nilai rata-rata kelas. Peningkatan juga bisa terlihat bila dilihat secara spesifik pada komponen-komponen tulisan peserta didik. Nilai yang terdata dalam setiap komponen adalah nilai rata-rata kelas sehingga bisa menunjukkan kekuatan komponen tulisan peserta didik dalam menunjang nilai akhir secara umum. Tabel berikut adalah tabel yang menunjukkan peningkatan keterampilan menulis peserta didik dilihat dari komponen tulisan.

Tabel 3. Perubahan komponen tulisan peserta didik

\begin{tabular}{llll}
\hline & Pre-test & Post-test 1 & Post-test 2 \\
\hline Isi $($ C) & 1.9 & 3.1 & 3.6 \\
Organisasi teks $(\mathrm{O})$ & 2 & 3.1 & 3.5 \\
Tata bahasa $(G)$ & 2 & 2.7 & 3.2 \\
Kosakata $(V)$ & 2.1 & 3 & 3.3 \\
Mekanik $(M)$ & 2.3 & 3.5 & 3.8 \\
\hline
\end{tabular}

Didalam tabel diatas bisa dilihat perubahan yang terjadi pada tiap komponen tulisan peserta didik di setiap tes akhir siklus. Dari pre-test hingga post-test 2, dapat terlihat komponen yang memiliki nilai rata-rata terendah adalah dalam aspek tata Bahasa atau grammar. Nilai rata-rata dari aspek grammar yang rendah menunjukkan bahwa peserta didik di kelas 11 IIS 1 memiliki kemampuan untuk menggunakan tata Bahasa yang tepat masih kurang. Peneliti yang juga bertindak sebagai guru sadar akan hal ini sehingga memasukkan strategi untuk melakukan tahapan menulis revisi kedalam pembelajaran. Pemberian tahapan revisi akan memberikan peserta didik kesempatan untuk mengoreksi hasil tulisan mereka dengan bantuan koreksi/feedback dari guru. Dengan berawal dari koreksi guru, peserta didik dapat melakukan perubahan-perubahan pada tulisan mereka. Tidak hanya koreksi guru, dalam tahapan pendekatan modelling of text pada Genre based approach di pertemuan kedua dianggap mampu membuat peserta didik melakukan revisi sekaligus membandingkan tulisan mereka dengan text sumber untuk mencari informasi-informasi tambahan yang masih ditemukan kelemahan. Dengan adanya kemauan dan kesempatan untuk melakukan peningkatan dalam komponen grammar selama dilakukan siklus 2, pada akhir post-test 2 komponen grammar sudah meningkat lebih baik.

Didalam tabel diatas juga dapat terlihat komponen tulisan yang memiliki nilai tertinggi sejak awal adalah mekanik tulisan. Komponen ini berkaitan dengan kaidah / aturan-aturan penulisan. Dikarenakan Bahasa ibu dari peserta didik yaitu Bahasa Indonesia memiliki kaidah penulisan yang mirip dengan Bahasa target yang digunakan yaitu Bahasa Inggris, peserta didik sudah terbiasa menulis dengan benar. 
Walaupun peserta didik sudah terbiasa menulis dengan kaidah yang benar, masih ditemukan dalam tulisan peserta didik kekurangan seperti contohnya kesalahan ejaan, penggunaan konjungsi, penggunaan huruf capital, tanda hubung, dst. Hal ini yang membuat nilai komponen ini tidak sempurna meskipun para subjek sudah banyak terpapar kaidah-kaidah penulisan yang benar.

Komponen tulisan yang lain yang mengalami peningkatan yang signifikan adalah aspek isi atau content. Aspek konten secara umum juga mengalami peningkatan dari pre-test. Peningkatan yang signifikan terlihat dari peningkatan sebesar 1.2 point. Peningkatan yang tinggi ini disebabkan oleh kemampuan peserta didik untuk mengembangkan ide-ide mereka menjadi lebih dalam. Kemampuan penjabaran ide paragraph menjadi paragraph yang utuh disebabkan dari proses pembimbingan guru untuk merevisi tulisan mereka dikelas. Pembimbingan dibantu dengan latihan penulisan text dalam pembelajaran membuat peningkatan ini dapat terjadi. Tidak hanya, dalam proses pembelajaran, perubahan juga diyakini oleh guru ketika mengoreksi hasil tulisan peserta didik dimana terjadi perubahan yang tampak jelas dari pre-test dan post-test. Komponen tulisan yang lain adalah organisasi teks. Aspek yang dinilai dari komponen ini berkaitan dengan keterpaduan antara paragraph dalam teks, kecocokan isi paragraph dengan struktur teks yang digunakan, dan kejelasan kalimat dalam teks. Sama seperti kasus peningkatan komponen isi teks, peningkatan dalam komponen ini juga disebabkan oleh kemampuan peserta didik dalam melakukan revisi tulisan mereka dengan cara membandingkan tulisan mereka dengan text sumber. Kegiatan ini memungkinkan peserta didik untuk tahu sejauh mana paragraph mereka saling terkait satu sama lain dibandingkan dengan teks model yang diberikan oleh guru. Sebagai tambahan, kejelasan antar paragraph juga dibantu dengan adanya proses modeling menggunakan bantuan ilustrasi dan video. Dengan adanya dua media pembantu tersebut, peserta didik bisa membayangkan aliran paragraph yang akan mereka buat.

Komponen terakhir yang bisa dianalisis adalah kosakata atau vocabulary. Komponen ini menilai keterampilan penggunaan kosakata, keluasan kosakata yang dimiliki, dan pemilihan kata yang tepat didalam kalimat. Komponen ini dirasakan peneliti memiliki kesamaan secara umum pada setiap peserta didik. Mengingat vocabulary yang dimiliki peserta didik dalam materi ini cenderung mirip satu sama lain. Hal ini bisa terlihat darikegiatan apersepsi ketika guru melakukan permainan chain word, peserta didik sering kebingungan dan meminta jeda karena tidak bisa menemukan kosakata yang lain daripada yang sudah disebutkan temannya. Di apersepsi yang lain yaitu Chinese whisper, peserta didik juga mengalami hambatan dalam pengejaan kosakata yang didapat. Ketika meminta bantuan dari teman sekelompok, jawaban yang diperoleh tetap sama. Ini menandakan bahwa mereka memiliki ragam vocabulary yang sama. Sebagai tambahan, ketika hasil tulisan peserta didik dikoreksi, tidak ada perbedaan signifikan dengan kata-kata yang digunakan antara pre-test dan post-tes. Perbedaan dapat terlihat dari penggunaan kosakata yang lebih luas setelah mereka membedah atau deconstruct the text dan membandingkan dengan text mereka. Pada tahapan itulah peserta didik mulai menambahkan kosakata-kosakata baru kedalam tulisan baru mereka sesuai dengan informasi dari text model yang mereka dapat.

Berdasarkan adanya peningkatan-peningkatan yang terjadi didalam hasil unjuk kerja menulis dan telah tercapainya indicator keberhasilan penelitian dimana lebih dari $75 \%$ peserta didik sudah memiliki nilai diatas KKM, maka penelitian dihentikan pada siklus 2. Pada akhirnya peserta didik kelas 11 IIS 1 dapat menunjukkan keterampilan menulis explanation text dengan benar yang terlihat dari baiknya nilai komponen-komponen tulisan mereka. Nilai tersebut mendongkrak nilai akhir mereka melampaui KKM. Berdasarkan informasi ini, dapat disimpulkan bahwa pengimplementasian Genre bsed approach dapat meningkatkan keteramplan menulis peserta didik kelas XI IIS 1.

\section{Simpulan}

Setelah Berdasarkan temuan dan hasil analisis pada hasil tindakan dan pembahasan, kesimpulan daripada penelitian ini menjawab rumusan masalah pada bab 1 . Kesimpulan yang dapat ditarik adalah sebagai berikut. Pertama, pengimplementasian Genre based approach dalam pembelajaran menulis text explanation berjalan dengan baik. Hal ini dibuktikan dari meningkatnya jumlah peserta didik yang melampaui KKM dari pre-test, post-test1, dan post-test 2 sebesar $21 \%$ ke $74 \%$ sampai akhir ke $94 \%$.

Kedua, pembelajaran text explanation menggunakan Genre based approach terbukti dapat meningkatkan keterampilan menulis text peserta didik. Nilai rata-rata peserta didik meningkat dari pretest yang dibawah KKM menjadi diatas KKM. Nilai rerata kelas pada pre-test sebesar 52.6 menjadi 76.8 pada post-tes 1 dan 87.6 pada post test 2 .

\section{Daftar Pustaka}

arikunto, S. (2017) Prosedur Penelitian: Suatu Pendekatan Praktek. Jakarta: Pt. Raneka Cipta.

Boardman, Cynthia. A, And Frydenberg, J. (2002) Writing To Communicate Paragraphs And Essays. University of California. San Fransisco: Longman. 
Hasan, M. K., \& Akhand, M. M. (2010) 'Approaches To Writing In Efl/Esl Context: Balancing Product And Process In Writing Class At Tertiary Level', Journal Of Nelta, 15, Pp. 1-2.

Kim, J., \& Kim, J. (2005) Teaching Korean University Writing Class. Asian Efl.

Mills, J. . (2000) Action Research: A Guideline For The Teacher Researcher. New Jersey: Prentice Hall, Inc.

Nidawati (2013) 'Belajar Dalam Perspektif Psikologi Dan Agama', Journal Of Chemical Information And Modeling, 53(9), Pp. 1689-1699.

Nurkholis (2013) 'Pendidikan Dalam Upaya Memajukan Teknologi Oleh: Nurkholis Doktor Ilmu Pendidikan, Alumnus Universitas Negeri Jakarta Dosen Luar Biasa Jurusan Tarbiyah Stain Purwokerto', 1(1), Pp. 24-44.

Oshima, Alice, \& Hogue, A. (No Date) Introduction To Academic Writing. New York: Pearson Education, Inc. Sismulyasih Sb, N. S. S. (2015) 'Peningkatan Keterampilan Menulis Manuskrip Jurnal Ilmiah Menggunakan Strategi Synergetic Teaching Pada Mahasiswa Pgsd Unnes', Primary: Jurnal Pendidikan Guru Sekolah Dasar, 4(1), P. 64. Doi: 10.33578/Jpfkip.V4i1.2724. 